\title{
PENGARUH PENDAPATAN ASLI DAERAH, DANA ALOKASI UMUM, DANA ALOKASI KHUSUS TERHADAP PRODUK DOMESTIK REGIONAL BRUTO
}

\author{
Ardian Luthfan Aditya \\ Universitas Pembangunan Nasional (UPN) Veteran Jawa Timur, Indonesia \\ Email: ardianluthfan@gmail.com
}

\begin{abstract}
Abstrak
Tujuan dilakukan penelitian ini untuk mengetahui pendapatan asli daerah, dana alokasi umum, dan dana alokasi khusus terhadap produk domestik regional bruto pada provinsi Daerah Istimewa Yogyakarta. Dalam penelitian ini menggunakan jenis data sekunder yang terdiri dari pendapatan asli daerah, dana alokasi umum, dana alokasi khusus dan produk domestik regional bruto kabupaten/kota di provinsi Daerah Istimewa Yogyakarta dari tahun 2013 hingga 2019. Data yang digunakan diperoleh dari publikasi mengenai keuangan daerah yang dipublikasikan oleh Badan Pusat Statistik Provinsi Daerah Istimewa Yogyakarta. Metode penelitian yang digunakan adalah regresi linier berganda dengan tahun penelitian 2013-2019. Hasil dari pengujian regresi linier berganda pada penelitian ini diperoleh bahwa pendapatan asli daerah (PAD) memiliki pengaruh positif dan signifikan terhadap PDRB, dana alokasi umum (DAU) memiliki pengaruh positif dan signifikan terhadap PDRB, serta dana alokasi khusus berpengaruh signifikan dan negatif terhadap PDRB. Berdasarkan hasil dari penelitian ini pemerintah disarankan melakukan peninjauan kembali mengenai pemanfaatan anggaran dari sisi pendapatan pemerintah sebagai upaya meningkatkan pertumbuhan ekonomi.
\end{abstract}

Kata Kunci: pendapatan asli daerah; dana alokasi umum; dana alokasi khusus; produk domestik regional bruto

\section{Abstract}

The purpose of this study to know the effect of original local government revenue, general allocation fund, special allocation fund to gross regional domestic product at The Special Region of Yogyakarta Province. This study uses secondary data consisting of local revenue, general allocation funds, special allocation funds and gross regional domestic product of districts/cities in the province of the Special Region of Yogyakarta from 2013 to 2019. The data used were obtained from publications on regional finance published by the Central Bureau of Statistics of the Special Region of Yogyakarta. The research method used is multiple linear regression with the research year 2013-2019. From result of multiple linear regression analysis at this research were found that the original local government revenue has positive and significant effect to gross regional domestic product, general allocation fund has positive and significant effect to to gross regional domestic product, and special allocation fund has significant and negative effect to to gross regional domestic product. Based on this research, the government is advised to review the use of the budget to increase economic growth.

$\begin{array}{ll}\text { How to cite: } & \text { Aditya, A, L., (2022) Pengaruh Pendapatan Asli Daerah, Dana Alokasi Umum, Dana Alokasi Khusus } \\ & \text { Terhadap Produk Domestik Regional Bruto, Syntax Idea, 4(1), https://doi.org/10.36418/syntax- } \\ & \text { idea.v4i1.1714 } \\ \text { E-ISSN: } & 2684-883 X \\ \text { Published by: } & \text { Ridwan Institute }\end{array}$


Keywords: original local government revenue; general allocation fund; special allocation fund; gross regional domestic product

\section{Received: 2021-12-22; Accepted: 2022-01-05; Published: 2022-01-20}

\section{Pendahuluan}

Pertumbuhan ekonomi merupakan salah satu indikator yang digunakan untuk mengukur keberhasilan pembangunan dalam suatu negara. Menurut (Prishardoyo, 2008) perkembangan sektor-sektor ekonomi dalam sebuah wilayah dapat diukur dengan nilai pertumbuhan ekonomi. Pembangunan dalam suatu negara meliputi tingkat pertumbuhan ekonomi, berkurangnya ketimpangan pendapatan dan kemiskinan pada masyarakat. Tingkat pertumbuhan ekonomi merupakan tujuan yang diutamakan oleh suatu pemerintahan. Tingkat pertumbuhan ekonomi dapat dipengaruhi oleh jumlah penduduk, jumlah barang modal, ketersediaan tanah, kekayaan alam, serta kemajuan teknologi menurut Subandi dalam (Yunianto, 2021).

Pemerintah di Indonesia membentuk reformasi dalam menunjang kesejahteraan masyarakat. Pemerintah menentukan sebuah kebijakan yang membahas pemerintahan daerah di Undang-Undang Nomor 32 Tahun 2004 mengenai perimbangan keuangan antara pemerintah pusat dan daerah. Kebijakan otonomi daerah sebagai bentuk upaya desentralisasi dalam pengelolaan keuangan daerah yang digunakan untuk meningkatkan kesejahteraan masyarakat serta meningkatkan pertumbuhan ekonomi. Dengan adanya kebijakan tersebut diharapkan dapat mengurangi ketimpangan ekonomi dan pemerataan pembangunan sesuai dengan daerah masing-masing untuk mengembangkan suatu wilayah sesuai dengan potensi yang dimiliki. Pendapatan dari suatu wilayah berasal dari Pendapatan Asli Daerah yang mencakup retribusi daerah, pajak, dan pengelolaan kekayaan daerah yang dipisah dan lain-lain. Pendapatan asli daerah yang sah, Dana Alokasi Umum, Dana Alokasi Khusus, Dana Bagi Hasil, Pinjaman daerah dan lain-lain adalah penerimaan yang digunakan untuk pendanaan pemerintah daerah. PAD dapat diibaratkan sebagai kemandirian keuangan daerah. Apabila jumlah PAD yang didapat oleh suatu daerah dibandingkan dengan dana bantuan dari pemerintah pusat maka daerah tersebut dapat dikatakan mandiri dengan jumlah PAD yang lebih besar menurut Tambunan dalam (Hananto, 2018).

Berdasarkan penelitian dari (Mawarni \& Abdullah, 2013) pendapatan asli daerah dan dana alokasi umum memiliki pengaruh signifikan terhadap pertumbuhan ekonomi. Hasil Penelitian dari (Anwar, Palar, \& Sumual, 2016) menunjukkan bahwa secara parsial DAU berpengaruh signifikan terhadap Pertumbuhan Ekonomi, DAK tidak berpengaruh dan tidak signifikan terhadap Pertumbuhan Ekonomi, PAD tidak berpengaruh dan tidak signifikan terhadap Pertumbuhan Ekonomi. Sedangkan secara simultan DAU, DAK dan PAD berpengaruh terhadap Pertumbuhan Ekonomi. Penelitian berikutnya dilakukan oleh (Oktafia, Soelistyo, \& Arifin, 2018) dengan judul Pengaruh Pendapatan Asli Daerah (PAD), Dana Alokasi Umum (DAU), Dana Alokasi Khusus (DAK) Terhadap Produk Domestik Regional Bruto (PDRB) Kabupaten/Kota di 
Provinsi Jawa Timur. Penelitian ini menggunakan metode analisis regresi linier berganda dengan menggunakan data panel. Dalam penelitian ini menunjukkan variabel pendapatan asli daerah, dana alokasi umum, dan dana alokasi khusus memiliki pengaruh yang signifikan dan bersifat positif terhadap PDRB. Adapun penelitian yang dilakukan oleh (Hananto, 2018) dengan judul Analisis Pengaruh Pendapatan Asli Daerah, Dana Alokasi Umum, Dana Alokasi Khusus, dan Belanja Modal Terhadap Produk Domestik Regional Bruto Kabupaten dan Kota di Provinsi Lampung yang menggunakan metode analisis regresi dengan data time series dan cross section. Penelitian ini menunjukkan bahwa PAD dan DAU berpengaruh signifikan positif terhadap PDRB, DAK tidak berpengaruh signifikan positif terhadap PDRB, dan Belanja Modal berpengaruh signifikan negative terhadap PDRB. Penelitian yang dilakukan (Jannah \& Nasir, 2018) dengan judul Analisis Pengaruh PAD, DAK, dan DAU Terhadap Pertumbuhan Ekonomi di Provinsi Aceh. Penelitian ini menggunakan model data panel dengan metode regresi linier berganda. Pada penelitian ini variabel pendapatan asli daerah tidak berpengaruh terhadap pertumbuhan ekonomi, sedangkan variabel dana alokasi umum dan dana alokasi khusus memiliki pengaruh signifikan namun bersifat negative terhadap pertumbuhan ekonomi di Provinsi Aceh. Beberapa penelitian yang dilakukan di berbagai daerah menunjukkan hasil yang berbeda - beda, hal tersebut meyakinkan peneliti bahwa penggunaan variabel PAD, DAU, dan DAK untuk melakukan analisis guna mengetahui seberapa besar pengaruh masing - masing variabel tersebut terhadap pertumbuhan ekonomi yang nantinya dapat digunakan sebagai referensi pemerintah dalam penyelenggaraan pembangunan daerah sesuai dengan potensi daerah masingmasing.

\section{Metode Penelitian}

Metode penelitian dalam penelitian ini menggunakan pendekatan kuantitatif dengan melakukan pengumpulan data sekunder yang diperoleh dari buku atau laporan publikasi yang diterbitkan oleh Badan Pusat Statistik (BPS) Provinsi Daerah Istimewa Yogyakarta pada tahun periode 2013 hinga 2019. Dalam penelitian ini menggunakan data produk domestik regional bruto, pendapatan asli daerah, dana alokasi khusus, dan dana alokasi umum kabupaten/kota di Provinsi Daerah Istimewa Yogyakarta. Alat analisis yang digunakan dalam penelitian ini menggunakan metode analisis regresi linier berganda dengan melakukan uji asumsi klasik lalu dilakukan uji hipotesis untuk pengambilan keputusan.

\section{Hasil dan Pembahasan}

Berdasarkan hasil dari analisis regresi linear berganda dengan data pendapatan asli daerah, dana alokasi umum, dana alokasi khusus dan produk domestik regional bruto pada Provinsi Daerah Istimewa Yogyakarta periode 2013-2019 dengan hasil sebagai berikut: PDRB = -268529,890 + 35,177pad + 6,932dau - 14,259dak

Berdasarkan persamaan tersebut dapat diuraikan sebagai berikut:

$\beta_{0}$ : Nilai Konstanta sebesar $-268529,890$ 
Menunjukkan apabila PAD (X1), DAU (X2), dan DAK (X3) dianggap tetap atau konstan maka PDRB (Y) akan menurun sebesar 268529,890 juta rupiah.

$\beta_{1}$ : Koefisien regresi $X_{1}\left(\beta_{1}\right):$ pad $=35,177$

Menunjukkan bahwa PAD (X1) berpengaruh positif, dapat disimpulkan apabila PAD mengalami perubahan sebesar 1 jutai rupiah maka PDRB akan mengalami perubahan sebesar 35,177 juta rupiah dengan asumsi X2 dan X3 konstan.

$\beta_{2}$ : Koefisien regresi $\mathrm{X}_{2}\left(\beta_{2}\right): \mathrm{DAU}=6,932$

Menunjukkan bahwa DAU (X2) berpengaruh positif dan dapat disimpulkan apabila DAU mengalami peningkatan sebesar 1 juta rupiah persen maka PDRB akan mengalami peningkatan sebesar 6,932 juta rupiah dengan asumsi variabel bebas yang lain konstan

$\beta_{3}:$ Koefisien regresi $\mathrm{X}_{3}\left(\beta_{3}\right): \mathrm{DAK}=-14,259$

Menunjukkan bahwa DAK (X3) berpengaruh negatif, dapat diartikan apabila DAK mengalami perubahan 1 juta rupiah maka PDRB akan mengalami penurunan sebesar 14,259 juta rupiah.

Koefisien Determinasi (R2) berguna untuk mengetahui seberapa jauh kemampuan model dalam memberikan informasi variabel dependen. Berikut nilai koefisien determinasi pada penelitian ini:

Tabel 1

Hasil Pengujian Koefisien Determinasi

\begin{tabular}{ccccc}
\hline Model & R & R Square & $\begin{array}{c}\text { Adjusted R } \\
\text { Square }\end{array}$ & $\begin{array}{c}\text { Std. Error of the } \\
\text { Estimate }\end{array}$ \\
\hline 1 & $.972^{\mathrm{a}}$ & .945 & .940 & $2.11934 \mathrm{E} 6$ \\
\hline
\end{tabular}

Dari tabel 1 nilai koefisien determinasi sebesar 0,945 yang berarti 94,5 persen dari seluruh pengamatan variabel independen pendapatan asli daerah (X1), dana alokasi umum (X2), dan dana alokasi khusus (X3) mampu menjelaskan variabel dependennya yaitu PDRB (Y) dan sisanya 5,5 persen dipengaruhi faktor lain diluar model.

Uji F digunakan untuk mengetahui adanya hubungan variabel independen terhadap variabel dependen secara bersama-sama. Berikut hasil perhitungan menggunakan program computer SPSS:

Tabel 2

Hasil Uji F

\begin{tabular}{ccccccc}
\hline \multirow{2}{*}{1} & \multicolumn{2}{c}{ Sum of } & & & & \\
Model & Squares & Df & Mean Square & F & Sig. \\
\hline \multirow{2}{*}{1} & Regression & $2.386 \mathrm{E} 15$ & 3 & $7.954 \mathrm{E} 14$ & 177.085 & $.000^{\mathrm{a}}$ \\
\cline { 2 - 7 } & Residual & $1.392 \mathrm{E} 14$ & 31 & $4.492 \mathrm{E} 12$ & & \\
\cline { 2 - 7 } & Total & $2.525 \mathrm{E} 15$ & 34 & & & \\
\hline
\end{tabular}


Pada tabel 2 yang dihasilkan dari program SPSS diperoleh nilai $\mathbf{F}_{\text {hïtung sebesar }}$ 177,085 dan nilai signifikansi sebesar 0,000 $<0,05$ yang berarti $\operatorname{PAD}(\mathrm{X} 1)$, DAU(X2), dan DAK(X3) secara simultan berpengaruh terhadap PDRB(Y). Pada

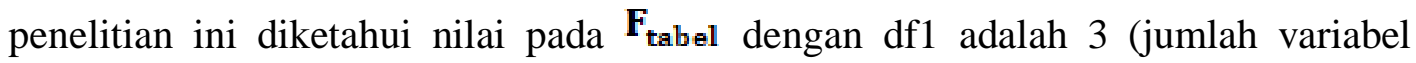
bebas/k) dan df2 32 (n-k) dengan demikian dapat diketahui nilai pada $\mathrm{F}$ tabel adalah 2,90. Hal tersebut dapat diketahui bahwa $\mathbf{F}_{\text {hitung }} \geq \mathbf{F}_{\text {tabel }}$

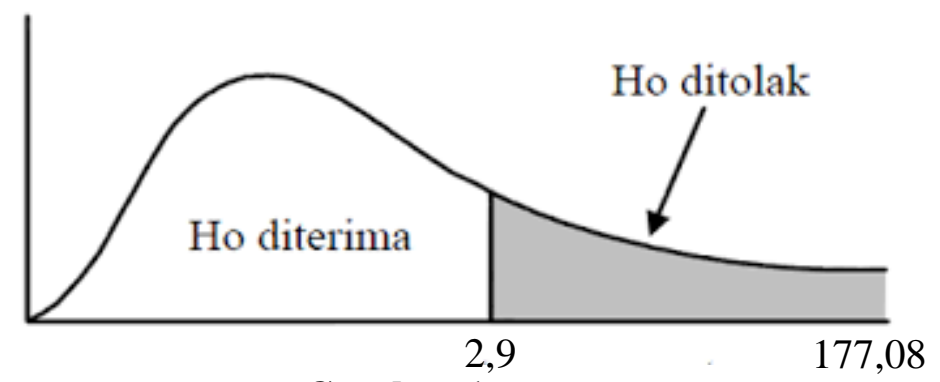

Gambar 1

Kurva Distribusi Uji F

Berdasarkan Gambar 1 dapat disimpulkan bahwa secara bersama - sama seluruh variabel bebas pada model ini berpengaruh signifikan dan positif terhadap variabel terikat. Uji T dilakukan untuk mengetahui pengaruh masing - masing variabel bebas terhadap variabel terikat. hasil dari uji $\mathrm{T}$ pada penelitian ini dijelaskan sebagai berikut:

Tabel 3

Hasil Uji T

\begin{tabular}{|c|c|c|c|c|c|c|c|}
\hline \multirow[b]{2}{*}{ Model } & \multicolumn{2}{|c|}{$\begin{array}{l}\text { Unstandardized } \\
\text { Coefficients }\end{array}$} & \multirow{2}{*}{$\begin{array}{c}\begin{array}{c}\text { Standardized } \\
\text { Coefficients }\end{array} \\
\text { Beta } \\
\end{array}$} & \multirow[b]{2}{*}{$\mathbf{T}$} & \multirow[b]{2}{*}{ Sig. } & \multirow{2}{*}{\multicolumn{2}{|c|}{$\begin{array}{c}\begin{array}{c}\text { Collinearity } \\
\text { Statistics }\end{array} \\
\text { Tolerance VIF } \\
\end{array}$}} \\
\hline & B & $\begin{array}{c}\text { Std. } \\
\text { Error }\end{array}$ & & & & & \\
\hline 1 (Constant) & -268592.890 & $2.108 \mathrm{E} 6$ & & -.127 & .899 & & \\
\hline $\mathrm{Pad}$ & 35.177 & 1.638 & .963 & 21.472 & .000 & .884 & 1.131 \\
\hline Dau & 6.932 & 2.878 & .123 & 2.409 & .022 & .686 & 1.457 \\
\hline Dak & -14.259 & 3.597 & -.196 & -3.964 & .000 & .728 & 1.374 \\
\hline
\end{tabular}

Berdasarkan Tabel 3 hasil dari uji $\mathrm{T}$ pada setiap variabel pada penelitian ini dijelaskan sebagai berikut:

1. Variabel Pendapatan Asli Daerah

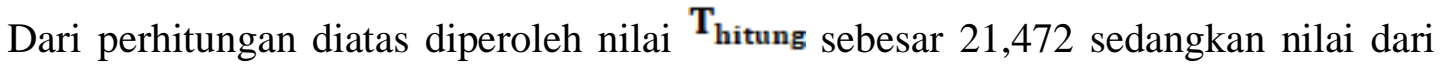
$\mathbf{T}_{\text {tabel diperoleh dari (a/2; n-k-1) sehingga }(0,025 ; 35-3-1) \text { dihasilkan nilai }} \mathbf{T}_{\text {tabel }}$ adalah 2,03951. Dari hasil tersebut diketahui bahwa nilai $\mathbf{T}_{\text {hitung } 21,472>\mathbf{T}_{\text {tabel }}}$ 2,03951. Dapat dibuktikan pada kurva distribusi uji T di bawah ini. 


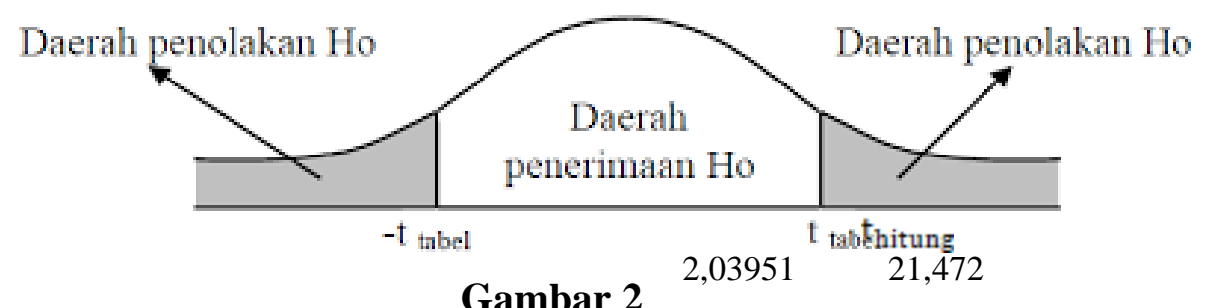

Kurva Distribusi Uji T Pendapatan Asli Daerah

Berdasarkan kurva uji $\mathrm{T}$ pada gambar 4.9 nilai $\mathrm{T}_{\text {hitung berada pada daerah }}$ penolakan Ho maka dapat disimpulkan bahwa secara parsial variabel pendapatan asli daerah berpengaruh signifikan dan positif terhadap PDRB di Provinsi D.I. Yogyakarta. Hasil penelitian ini sejalan dengan penelitian (Rarung, 2016). yang menghasilkan pendapatan asli daerah secara parsial berpengaruh terhadap PDRB di Kota Manado.

2. Variabel Dana Alokasi Umum

Dari perhitungan diatas diperoleh nilai $\mathbf{T}_{\text {hitung }}$ sebesar 2,409 sedangkan nilai dari $\mathbf{T}_{\text {tabel }}$ diperoleh dari ( $\left.\mathrm{a} / 2 ; \mathrm{n}-\mathrm{k}-1\right)$ sehingga $(0,025 ; 35-3-1)$ dihasilkan nilai $\mathbf{T}_{\text {tabel }}$ adalah 2,03951. Dari hasil tersebut diketahui bahwa nilai $\mathbf{T}_{\text {hitung }} 2,409>\mathbf{T}_{\text {tabel }}$ 2,03951. Dapat dibuktikan pada kurva distribusi uji T di bawah ini.

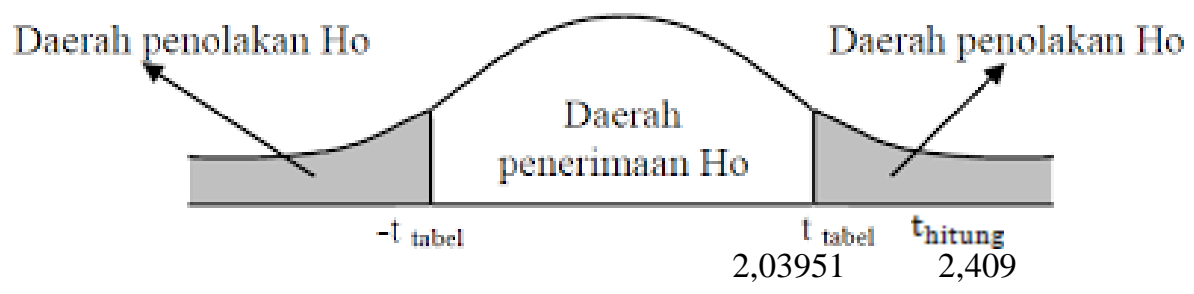

Gambar 3

Kurva Distribusi Uji T Dana Alokasi Umum

Berdasarkan kurva uji $\mathrm{T}$ pada gambar 4.10 nilai $\mathbf{T}_{\text {hitung }}$ berada pada daerah penolakan Ho maka dapat disimpulkan bahwa secara parsial variabel dana alokasi umum berpengaruh signifikan dan positif terhadap PDRB di Provinsi D.I. Yogyakarta. Hasil dari penelitian ini sejalan dengan penelitian yang dilakukan (Mafahir \& Soelistiyo, 2017) yang menghasilkan dana alokasi umum memiliki pengaruh positif dan signifikan terhadap PDRB Kabupaten/Kota di Provinsi Nusa Tenggara Barat.

3. Variabel Dana Alokasi Khusus

Dari perhitungan diatas diperoleh nilai $\mathbf{T}_{\text {hïtung }}$ sebesar -3,964 sedangkan nilai dari $\mathbf{T}_{\text {tabel }}$ diperoleh dari $(\mathrm{a} / 2 ; \mathrm{n}-\mathrm{k}-1)$ sehingga $(0,025 ; 35-3-1)$ dihasilkan nilai 
$\mathbf{T}_{\text {tabel }}$ adalah 2,03951. Dari hasil tersebut diketahui bahwa nilai $\mathbf{T}_{\text {hïtung }}-3,964<$ $\mathbf{T}_{\text {tabel }}$ 2,03951. Dapat dibuktikan pada kurva distribusi uji $\mathrm{T}$ di bawah ini.

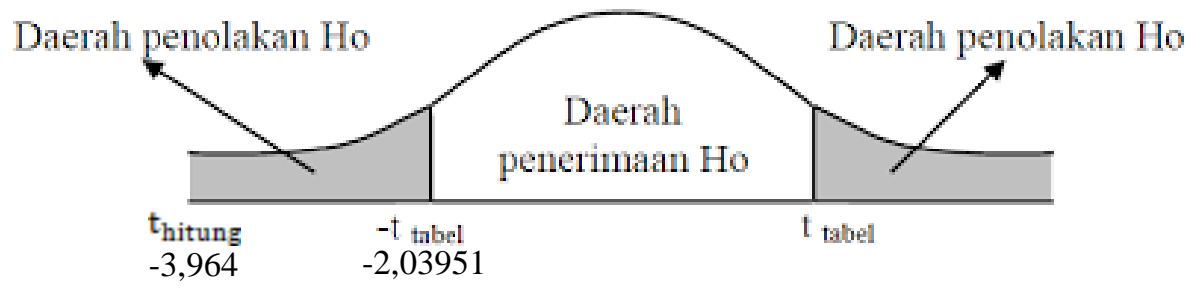

\section{Gambar 4}

Kurva Distribusi Uji T Dana Alokasi Khusus

Berdasarkan kurva uji $\mathrm{T}$ pada gambar 4.10 nilai $\mathbf{T}_{\text {hitung }}$ berada pada daerah penolakan Ho maka dapat disimpulkan bahwa secara parsial variabel dana alokasi khusus berpengaruh signifikan dan negatif terhadap PDRB di Provinsi D.I. Yogyakarta.

Berdasarkan hasil pengolahan data diatas dapat diketahui variabel independen Pendapatan Asli Daerah, Dana Alokasi Umum, dan Dana Alokasi Khusus secara simultan berpengaruh signifikan dan positif terhadap Produk Domestik Regional Bruto di Provinsi D.I. Yogyakarta pada tahun 2013-2019. Dan hasil pengujian penelitian yang dilakukan secara parsial variabel independen berpengaruh terhadap variabel dependen namun tidak semua variabel independen memberikan pengaruh yang positif yaitu variabel Dana Alokasi Khusus.

Variabel independen pendapatan asli daerah memiliki pengaruh signifikan terhadap produk domestik regional bruto di Provinsi D.I. Yogyakarta pada tahun 20132019 secara parsial/individu. Hal tersebut dapat disimpulkan bahwa terdapat hubungan positif antara pendapatan asli daerah dengan produk domestik regional bruto. Setiap adanya kenaikan nilai pada pendapatan asli daerah akan meningkatkan nilai produk domestik regional bruto.

Pada hasil pengujian ini menunjukkan bahwa dana alokasi umum berpengaruh signifikan dan positif terhadap PDRB. Hasil penelitian ini sejalan dengan penelitian yang dilakukan Mafahir A tahun 2013 yang menghasilkan dana alokasi umum memiliki pengaruh positif dan signifikan terhadap PDRB Kabupaten/Kota di Provinsi Nusa Tenggara Barat.

\section{Kesimpulan}

Berdasarkan hasil penelitian mengenai Pengaruh Pendapatan Asli Daerah (PAD), Dana Alokasi Umum (DAU), Dana Alokasi Khusus (DAK) terhadap Pertumbuhan Ekonomi Kabupaten/Kota Provinsi Daerah Istimewa Yogyakarta yang telah dilakukan pada penelitian, dapat diperoleh beberapa kesimpulan sebagai berikut : Perkembangan Produk Domestik Regional Bruto, Pendapatan Asli Daerah, Dana Alokasi Umum, dan Dana Alokasi Khusus Kabupaten/Kota Provinsi Daerah Istimewa Yogyakarta mengalami peningkatan pada setiap tahunnya mulai dari tahun 2013 hingga tahun 2019. 
Hasil pengujian melalui Uji Regresi Linear Berganda menunjukan Pendapatan Asli Daerah (PAD) berpengaruh positif terhadap pertumbuhan ekonomi Kabupaten/Kota DIY dapat diartikan apabila angka Pendapatan Asli Daerah (PAD) meningkat maka angka Produk Domestik Bruto DIY juga akan ikut meningkat. PAD ialah sumber pembelanjaan daerah ketika PAD meningkat, dana pemerintah daerah akan lebih tinggi dan tingkat kemandirian daerah juga akan ikut meningkat, dengan ini maka pemerintah daerah harus lebih memahami dan meningkatkan potensi yang dimiliki daerah guna meningkatkan PDRB. Hasil dari Dana Alokasi Umum berpengaruh positif terhadap Produk Domestik Regional Bruto Kabupaten/Kota DIY. Dimana ketika angka DAU naik maka akan meringankan kebutuhan yang dimiliki suatu daerah. Dana alokasi khusus berpengaruh negatif terhadap PDRB Kabupaten/Kota DIY. Ini dikarenakan DAK yang didapatkan pemerintah daerah dari APBN yang nantinya dialokasikan guna membiayai kebutuhan daerah dalam rangka mendanai kebutuhan pembangunan infrastruktur, pendidikan, kesehatan serta sarana dan prasarana pemerintahan daerah yang nantinya dapat menunjang perkembangan ekonomi belum dialokasikan dengan maksimal. Oleh sebab itu apabila semakin besar DAK yang diterima pemerintah daerah digunakan dengan maksimal, akan semakin baik juga pembangunan yang dilakukan pada daerah tersebut. Dengan adanya peningkatan pertumbuhan perekonomian pada suatu wilayah maka kesejahteraan masyarakat juga ikut meningkat. Pemerintah dan masyarakat harus bersama-sama saling mendukung adanya pembangunan ekonomi. 


\section{BIBLIOGRAFI}

Agustina, T., Gerhana, W., \& , S. (2020). The Effect of Locus of Control, Learning, and Adversity Quotient towards Micro Business Success (Study on Entrepreneurship under Foster Group of the Banjarmasin Regional Government). Journal of Wetlands Environmental Management. Google Scholar

Anonim. (2019). Berita Resmi Statistik DIY. Bps.Go.Id.

Anwar, M. L., Palar, S. W., \& Sumual, J. I. (2016). Pengaruh Dau, Dak, Pad Terhadap Pertumbuhan Ekonomi Dan Kemiskinan (Kota Manado Tahun 2001-2013). Jurnal Berkala Ilmiah Efisiensi, 16(2), 218-232. Google Scholar

Ardiyanti, R., Jokolelono, E., \& Sading, Y. (2018). Pengaruh Pendapatan Asli Daerah (Pad), Dana Alokasi Umum (Dau), Dana Alokasi Khusus (Dak) Terhadap Produk Domestik Regional. Jurnal Ilmu Ekonomi JIE, 72-83.

Bakhirnudin, A. (2013). Economics Development Analysis Journal. 2(4), 338-350. Google Scholar

Hananto, F. D. (2018). Analisis Pengaruh Pendapatan Asli Daerah, Dana Alokasi Umum, Dana Alokasi Khusus, dan Belanja Modal Terhadap Produk Domestik Regional Bruto Kabupaten dan Kota di Provinsi Lampung (2012-2016). Photosynthetica, 2(1), 1-13. Google Scholar

Hananto Fiant Dwi. (2018). Analisis Pengaruh Pendapatan Asli Daerah, Dana Alokasi Umum, Dana Alokasi Khusus, dan Belanja Modal Terhadap Produk Domestik Regional Bruto Kabupaten dan Kota di Provinsi Lampung (2012-2016). 2018.

Jannah, K., \& Nasir. (2018). Analisis Pengaruh PAD, DAK, dan DAU terhadap Pertumbuhan Ekonomi di Provinsi Aceh. Jurnal Ilmiah Mahasiswa (JIM), 3(2), 248-255. Google Scholar

Kusumawati, L., \& Wiksuana, I. G. B. (2018). Pengaruh Pendapatan Daerah Terhadap Pertumbuhan Ekonomi Di Wilayah Sarbagita Provinsi Bali. E-Jurnal Manajemen Universitas Udayana, 7(5), 2592. Google Scholar

Mafahir, A., \& Soelistiyo, A. (2017). Analisis Pengaruh Pad, Dau Dan Dak Terhadap Pdrb Kabupaten/Kota Di Provinsi Nusa Tenggara Barat. Jurnal Ilmu Ekonomi, 1, 143-152. Google Scholar

Mawarni, Darwanis, \& Syukriy, A. (2013). Dampaknya Terhadap Pertumbuhan Ekonomi. Jurnal Akuntansi Pascasarjana Universitas Syiah Kuala, Volume 2,(November 2019), 80-90.

Nachrowi, \& Djalal. (2017). Ekonometrika untuk analisis ekonomi dan keuangan: Pendekatan populer dan praktis / Nachrowi Djalal Nachrowi, Hardius Usman | Perpustakaan UIN Sultan Syarif Kasim Riau. 
Oktafia, M. A., Soelistyo, A., \& Arifin, Z. (2018). Pengaruh Pendapatan Asli Daerah ( Pad ), Dana Alokasi Umum ( Dau ), Dana Alokasi Khusus (Dak) Terhadap Produk Domestik Pendahuluan Pembangunan daerah sebagai bagian integral dari pembangunan nasional pada hakekatnya adalah upaya untuk meningkatkan kapas. Jurnal Ilmu Ekonomi, 2, 53-62. Google Scholar

Permanasari, W. A. (2014). Pengaruh Dana Alokasi Umum (Dau), Dana Alokasi Khusus (Dak), Pendapatan Asli Daerah (Pad), Dan Belanja Modal Terhadap Pertumbuhan Ekonomi (Studi Kasus Kabupaten/Kota Di Provinsi Jawa Tengah Tahun 2009-2011).

Pradana, R. S. (2019). Analisis Prioritas Pembangunan Daerah Berdasarkan Pengaruh Regional, Spesialisasi Daerah, Dan Keunggulan Kompetitif Ekonomi Sektoral Di Kabupaten Aceh Jaya. Jurnal Litbang Sukowati: Media Penelitian Dan Pengembangan. Google Scholar

Prishardoyo, B. (2008). Analisis Tingkat Pertumbuhan Ekonomi Dan Potensi Ekonomi Terhadap Produk Domestik Regional Bruto (Pdrb) Kabupaten Pati Tahun 20002005. Analisis Tingkat Pertumbuhan Ekonomi Dan Potensi Ekonomi Terhadap Produk Domestik Regional Bruto (Pdrb) Kabupaten Pati Tahun 2000-2005, 1(1), $1-9$.

Qomariyahti, N. D., \& Hermanto, S. B. (2013). Pengaruh Pad, Dau, Dak, Dan Dbh Terhadap Pengalokasian Belanja Modal. Accounting Analysis Journal, 2(1). Google Scholar

Rarung, P. (2016). Pengaruh Pad Dan Dau Terhadap Pdrb Di Kota Manado. Jurnal Berkala Ilmiah Efisiensi, 16(3), 449-460. Google Scholar

Setiyawati, A., \& Hamzah, A. (2007). Analisis Pengaruh Pad, Dau, Dak, Dan Belanja Pembangunan Terhadap Pertumbuhan Ekonomi, Kemiskinan, Dan Pengangguran: Pendekatan Analisis Jalur. Jurnal Akuntansi Dan Keuangan Indonesia, 4(2), 211228.

Siagian, E. (2018). Pengaruh Pendapatan Asli Daerah (Pad), Dana Alokasi Umum (Dau), Dana Alokasi Khusus (Dak) Terhadap Pertumbuhan Ekonomi Di Provinsi D.I. Yogyakarta Tahun 2010-2016. Prodi Akuntansi, 51(1), 51.

Siswiyanti, P. (2017). Pengaruh Pad, Dau, Dak Terhadap Pertumbuhan Ekonomi Dengan Belanja Modal Sebagai Variabel Intervening. AKRUAL: Jurnal Akuntansi, 7(1), 1. Google Scholar

Suandi, I. (2016). Dana Alokasi Terhadap Pertumbuhan. Google Scholar

Wijanarko, D. (2015). Pengaruh Pendapatan Asli Daerah (Pad), Dana Alokasi Umum (Dau), Dan Dana Alokasi Khusus (Dak) Terhadap Pertumbuhan Ekonomi Di Kabupaten/Kota Provinsi Jawa Tengah Periode 2012-2013. 


\section{Copyright holder:}

Ardian Luthfan Aditya (2022)

\section{First publication right:}

Syntax Idea

This article is licensed under:

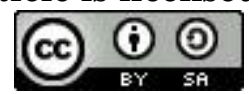

